\title{
Karl Marx e a Liberdade: de Jacobino a Comunista
}

Joana Salém Vasconcelos

\section{Resumo:}

A liberdade se tornou um valor prioritário dos movimentos sociais na modernidade. Karl Marx foi um dos porta-vozes filosóficos e políticos mais importantes das forças sociais que lutaram pela liberdade, levando o conceito às últimas conseqüências. Esse artigo expõe o desenvolvimento do conceito de liberdade no jovem Marx, entre I840 a I845. Articula temas como liberdade de imprensa, liberdade e luta de classes, liberdade e alienação, e liberdade e revolução. Cada um destes temas contribui para explicar a inflexão do Marx jacobino ao Marx comunista, eixo hipotético que sustenta o artigo, e que possui como fio condutor o conceito de liberdade.

Palavras-chave: Liberdade, Karl Marx, jacobinismo, proletariado, revolução. 
"Aquele que não está pronto para destruir o que construiu permanecerá sempre nesta terra que nunca é segura", Hariri, escritor árabe medieval (HARIRI, escritor árabe medieval, apud MARX, I979, p.6)

\section{Introdução}

A evolução do conceito de liberdade em Karl Marx está diretamente ligada ao seu posicionamento político ativo em seu contexto histórico. Daí que, na interpretação de György Lukács e de Michael Löwy, Marx desenvolveu seu comunismo a partir da superação daquilo que ambos chamam de "jacobinismo" ou democratismo radical. Sua filosofia política se transformou muito entre I840 e I845, e nesse pequeno intervalo é possível identificar a virada de um Marx democrata a um Marx comunista revolucionário. A inflexão que sofre o conceito de liberdade, do jacobinismo ao comunismo, é parte de um processo revolucionário da teoria. Lukács atesta: "entre I842 e I843, Marx percorreu teoricamente o caminho que, 50 anos antes, de Marat a Babeuf, o jacobinismo havia percorrido na prática" (LUKÁCS, 2009b, p. I40). Impossível separar o conceito de liberdade em Marx de sua definição de Revolução, já que para ele a conquista da liberdade humana é necessariamente revolucionária, seja por sua admiração histórica pela revolução jacobina, seja pela desilusão política com a burguesia acompanhada da posterior identificação do proletariado como novo e potente sujeito revolucionário emancipador. Marx é um admirador dos radicais da revolução burguesa na França, no contexto de um Estado Prussiano enredado nas malhas decadentes do absolutismo burocrático. A aristocracia prussiana conduziu uma Restauração sem mesmo ter havido Revolução, e o recrudescimento do regime leva Marx a se identificar politicamente com o radicalismo pequeno burguês, aparentemente libertário, até meados de I842. Em I843, demonstra desilusão com a burguesia liberal alemã e, atento ao discurso dos camponeses das províncias prussianas, rompe com a provisória aliança com a burguesia radical e seus correspondentes teóricos. A liberdade que Marx defende e busca, nesse momento, não é palavra que cai bem nos discursos dos proprietários de terras, pois não combina com seus verdadeiros interesses. Em I843, Marx estabelece um conteúdo mais social que político para definir a luta pela liberdade. Em I844, renova sua visão da alienação, aprende com os movimentos socialistas franceses e as primeiras revoltas proletárias na Prússia. A combinação dialética coordenada entre observação da realidade e permanente reformulação teórica da busca 
humana pela liberdade permite a Marx fazer do comunismo, num sistema sócioprodutivo que merece o estatuto de científico.

\section{Marx e a Liberdade de Imprensa: Um Jacobino na Gazeta Romana}

"Quando uma liberdade específica é questionada, questiona-se toda a liberdade", (MARX, I979, p. 7I)

Quando Marx assumiu sua atividade jornalística em I842, a relativa autocrítica que rascunhou na sua Tese de Doutorado ${ }^{\mathrm{I}}$, sobre as deficiências da filosofia alemã, cuja aparente vocação era "fechar-se em si mesma", pôde ser vivida com pragmatismo político. A Gazeta Renana sob a direção de Karl Marx adotou uma linha editorial mais enfática contra o absolutismo e a mordaça política. Marx produziu artigos contra o falso romantismo do Antigo Regime, contra as instruções do Rei sobre a censura, contra as tendências da Assembleia da Dieta, contra a escola histórica de direito, contra a lei sobre os roubos de lenha, entre outros. Marx acreditava então na necessidade de "fazer nascer um liberalismo alemão e não francês" (MARX, I979, p. I33, grifo nosso). Nesse período, a dimensão nacional da luta emancipatória de Marx é marcante, no projeto de um liberalismo autenticamente germânico. O pragmatismo político de Marx, já nos primeiros meses da Gazeta Renana, entra em rota de colisão com Bruno Bauer e os jovens hegelianos, estes muito preocupados com a crítica da religião e com a pregação do ateísmo como essência da emancipação humana. A postura jovem hegeliana, para Marx, não atingia a disputa central contra o absolutismo, e servia como "isca da censura" pela escandalosa (e estéril) intolerância contra qualquer religião. Neste período, Marx entra em contato com o materialismo de Ludwig Feuerbach (I804 - I872) e lhe presta significativa consideração. Sob dois aspectos, Marx está em processo de distanciamento do idealismo objetivo de Hegel: primeiro, a idéia de Estado, para Marx, é a idéia programática do Estado democrático radical dos jacobinos, e para Hegel, uma noção universal abstrata coroada pela defesa da Monarquia parlamentar; segundo, a "reconciliação" de Hegel com a realidade do regime absolutista é, para Marx, contraditória com a noção hegeliana de identidade entre realidade e razão. Em Marx, essa identidade

I Em I84I, Karl Marx apresentou sua tese de doutorado na Universidade de Iena com título "Diferenças entre a Filosofia da Natureza em Demócrito e Epicuro". Demócrito e Epicuro foram os dois filósofos mais materialistas da antiguidade. Com esta tese, Marx buscou diferenciá-los, polemizando com Hegel que valorizava mais as suas semelhanças. Nesta tese também rascunhou princípios da relação dialética entre filosofia e realidade. György Lukács possui estudo de I955 sobre o assunto. 
inspira supremacia da realidade sobre a "anti razão", um combustível para aristocracia prussiana. Isto é, coerência entre realidade e razão deveria conduzir à defesa da derrocada do absolutismo.

Em seu artigo Sobre a Censura e a Liberdade de Opinião, publicado em I842 na Gazeta Renana, Marx defende uma concepção de liberdade mais jacobina do que a dos proprietários burgueses da revista que dirige. $\mathrm{O}$ artigo é estruturado em duas respostas a dois interlocutores reais, cujos depoimentos foram registrados na Assembleia de Representantes do Estado Prussiano: um aristocrata e um burguês. Marx combate ambos. Defende que "a imprensa em geral é a consumação da liberdade humana. Portanto, onde existir imprensa, existirá liberdade de imprensa" (MARX, I979, p. 45). Ou seja, ou a imprensa é livre, ou não se deve chamá-la de imprensa; e ou a liberdade humana inclui a imprensa, ou estará incompleta. A importância dada à liberdade de imprensa é uma manifestação do jacobinismo de Marx, na sua atividade de disputa política pragmática. Marx é um agitador das lutas travadas décadas antes pelo liberalismo democrático radical de países como a França e os Estados Unidos.

Sua resposta ao interlocutor aristocrático é uma articulada teia de pressupostos hegelianos acerca do sistema de direito positivo, associado a propostas políticas de tonalidade jacobina. Suas diversas definições de liberdade combinam o otimismo com a crítica da realidade prussiana:

A liberdade é a tal ponto a essência do homem que mesmo seus opositores a reconhecem, posto que a combatem [...] Se uma imprensa livre e a liberdade de imprensa devem ser rejeitadas como a consumação da liberdade universal, a censura e uma imprensa censurada representariam ainda mais a consumação de uma liberdade particular. (MARX, I979, p. 45-46)

A influência de determinado pensamento de $\mathrm{Hegel}^{2}$ é visível: a liberdade subjetiva (particular) se choca contra a liberdade universal. Ou seja, a liberdade de imprensa assume uma força universal de tonalidade jacobina contra a particularidade da censura. Há um embate na Assembleia de Representantes do Reno entre duas leis: a "lei da censura" contra a "lei da imprensa". Marx defende a lei da imprensa, que mais flexível à liberdade de opinião: "A lei da imprensa pune o abuso da liberdade. A lei da censura pune a liberdade como se fosse um

2 György Lukács diferencia três momentos do pensamento de Hegel, correlacionados às cidades em que o filósofo viveu: Berna (I793 a I796), Frankfurt (I797 a I800) e Iena (I80I a I807). "Grise de Frankfurt" é o termo que emprega para explicar a inflexão de Hegel da resistência à aceitação da liberdade subjetiva como direito positivo universal. Do artigo "O Jovem Hegel. Os novos problemas da pesquisa Hegeliana", escrito por Lukács em I949 (2009a). 
abuso" (MARX, I979, p. 5I), diz. Para argumentar em defesa da lei da imprensa contra a lei da censura, Marx se utiliza de uma filosofia política rigorosamente hegeliana, combinada com pragmatismo jacobino. Diz que a lei da censura não é verdadeiramente uma lei, mas sim uma medida policial; ao contrário, a lei da imprensa é uma lei verdadeira, posto que é a liberdade convertida em vontade consciente do Estado. Aqui, Lei e Liberdade são conceitos tão conectados quanto em Hegel: "Um texto legal é a bíblia da liberdade de um povo" (MARX, I979, p. 52), afirma Marx. A conexão com a filosofia hegeliana não para aqui. Marx usa a dialética especulativa para explicar a relação do povo com a imprensa. A imprensa seria a exteriorização da liberdade subjetiva do povo, ou a realização de uma liberdade geral "para si", como auto-consciência. A imprensa livre é "o espelho intelectual no qual o povo se vê, e a visão de si mesmo é a primeira condição de sabedoria" (MARX, I979, p. 54). O momento dialético da conversão do "povo em si" ao "povo para si" é a imprensa livre. Como espelho do povo e essência intelectual da liberdade, a imprensa deve pertencer à esfera pública da "ética superior". De Hegel, Marx se apropria de um conceito de comunidade pública, e de uma crítica da predominância do "homem privado" na modernidade.

A resposta de Marx ao interlocutor burguês é mais interessante, porque exige mais radicalismo do autor. O burguês jornalista, de seu universo utilitário, diz que a liberdade de imprensa é valorosa enquanto liberdade de ofícios. Contra essa concepção, Marx desenvolve uma crítica nova, inspirada em Voltaire (François-Marie Arouet, I694 - I778). Voltaire diz: "Esta conversa de liberdades, de privilégios, pressupõe submetimento. As liberdades são isenções da servidão geral" (apud MARX, I979, p. 72, nota II). E Marx complementa, um século depois: "em geral, não amamos aquela 'liberdade' que tem valor somente no plural. A Inglaterra é uma prova do perigo que representa para a liberdade o horizonte restringido das liberdades" (MARX, I979, p. 68). As liberdades constituem, no seu plural, pedaços avulsos e corporativos sem todo, particularidades vazias de essência, aparência sem horizonte especulativo com o universal. As liberdades são "em si", não são "para si", e não alcançam estratégia que as aproxime da "vontade geral". Com isso, apesar do mérito do interlocutor, de "não cair no raciocínio obscuro e confuso daqueles alemães liberais que pensam honrar a liberdade, colocando-a no estrelado céu da imaginação em vez de plantá-la no sólido chão da realidade" (MARX, I979, p. 6I), Marx alerta o perigo das liberdades repartidas em parcelas quando estas perdem seu horizonte essencial. Afirma Marx que "transformar a liberdade de imprensa numa espécie de liberdade de ofícios é defendê-la de tal forma que essa defesa significaria sua morte"3(MARX, I979, p. 63). Trata-se da defesa da liberdade universal como 
centro essencial de toda liberdade particular. Anular a liberdade de imprensa pela liberdade de ofícios significa abrir mão dos princípios especulativos da representação popular "para si", em troca da oficialidade técnica da profissão de escritor. O jornalista, para Marx, não é um técnico, oficial da opinião que briga por suas condições corporativas; ao contrário, a tarefa do jornalista é representar a voz do povo e radicalizar as condições democráticas da sociedade. Assim, com seu jacobinismo saltando-lhe às veias, associa brilhantemente o interlocutor burguês ao interlocutor aristocrático. A liberdade de imprensa, concebida pelo burguês como a "liberdade do ofício de escritor", é o passo anterior à oficialidade absoluta da censura abraçada pelo aristocrata. Sintetiza:

A primeira liberdade de imprensa consiste em que ela não seja um ofício [...]. Não será possível certamente chegar à liberdade de imprensa através do recrutamento de um grupo de escritores oficiais saídos das suas próprias fileiras [...]. Esse tipo de liberdade de imprensa deseja introduzir a oligarquia da mente. (MARX, i979, p. 65, 66, 67)

Desde então, Marx enxerga o corporativismo técnico do discurso burguês como o véu que encobre a dominação oligárquica mais tradicional. Dessa forma que a Assembleia de Representantes do Reno se revela para Marx como uma "barganha não intelectual e uma pechincha sobre quanta liberdade deveria ter a liberdade de imprensa", pendulando entre "a obstinação deliberada do privilégio e a impotência natural de uma semi liberal vacilação” (MARX, I979, p. 68 e p.70).

Além da liberdade de imprensa, outra dimensão da liberdade que Marx notou violada foi a tradição camponesa de acesso às florestas. No artigo escrito para Gazeta Renana, Debates sobre a lei contra os furtos de lenha, também de I842, Marx assume o lado dos camponeses no conflito sócio-jurídico e afirma: "quando os privilegiados do direito escrito apelam a seu próprio direito consuetudinário, eles querem impor, em vez de conteúdo humano, a configuração bestial do direito, que agora se tornou na realidade uma mera máscara animalesca" (MARX ; LUKÁCS, 2009b, p. I39). Tanto o conteúdo humano universal da filosofia do direito de Hegel, quanto a bandeira burguesa da igualdade de direitos parecem insuficientes para armar Marx na defesa da liberdade. Por isso, com essas palavras, Marx animaliza o que há de mais valoroso na tradição revolucionária burguesa: o direito. O direito escrito viola o direito milenar. Os privilegiados do direito manipulam seu próprio direito para violar o direito alheio. Até mesmo

3 Refere-se à filosofia alemã em geral, e aos jovens hegelianos em particular. 
uma rigorosa aplicação da definição liberal ortodoxa de liberdade, nesse caso criaria um impasse: a liberdade técnica do proprietário dos bosques e a liberdade tradicional do camponês se violam mutuamente. A liberdade de um setor social atravessa a liberdade de outro. Portanto, não podem ser "liberdades", pois o rigor liberal obriga o entendimento a associar a liberdade com o isolamento. Liberdades que se tornam obstáculos irreconciliáveis umas às outras. O direito aristocrático-burguês diz que a prerrogativa é do proprietário. Marx analisa:

Um certo tipo de propriedade tinha um caráter equívoco, que não a definia inequivocamente nem como propriedade privada nem como propriedade comum [...] portanto, sobrevive nestes costumes da classe pobre um sentido instintivo de direito, cuja raiz é positiva e legítima. E a forma do direito consuetudinário é, neste caso, igualmente conforme à natureza, assim como a existência da própria classe pobre constitui até agora um mero costume da sociedade civil burguesa, que ainda não encontrou um lugar apropriado no âmbito da articulação consciente do Estado. (MARX; LUKÁGS, 2009b, p. I40)

Marx ironiza com a crítica hegeliana ao jusnaturalismo. Porque o direito positivo e legítimo está do lado camponês, e o direito natural é adotado pelo proprietário, tanto para incriminar o camponês, quanto para naturalizar a pobreza.

Do artigo Sobre a Censura e a Liberdade de Opinião ao artigo Debates sobre a lei contra os furtos de lenha, Marx amplia sua desconfiança sobre o Estado aristocrático-burguês e diagnostica a particularidade burguesa com maior rigor científico. No primeiro, Marx acredita num liberalismo justo, correspondente a um sistema de leis universais verdadeiras, contra um semi liberalismo vacilante e mesquinho. Já no segundo, poucos meses depois, Marx afirma que a burguesia transforma o Estado em "orelhas, olhos, braços e pernas com os quais o interesse do proprietário de florestas escuta, espiona, avalia, protege, apodera-se e corre" (MARX; LÖWY, I997, p. 60), isto é, o Estado é o corpo da burguesia. Apesar desta percepção crítica materialista, o hegelianismo de Marx está latente. Pelo menos por quatro princípios em comum: primeiro, o universal não se constitui do agregado de particulares concretos; segundo, enxergar o Estado como uma somatória de indivíduos o transforma em instrumento de interesses autônomos já existentes antes do Estado, portanto numa instituição desnecessária; terceiro, o cidadão, espírito genérico do Estado universal, se subordinado a interesses materiais, desvirtua o sistema político em sua totalidade; quarto, os pobres são vítimas sociais passivas. 
No início de I843, a Gazeta Renana foi fechada pelo Estado prussiano. A facção burguesa do jornal sequer protestou e assumiu uma atitude complacente. Com uma linha política de retomar a aliança com o rei e repactuar com o governo, os acionistas da Gazeta Renana poderiam encontrar outros veículos. Os novos hegelianos, divididos desde I842, protestaram em vão. Neste período Marx encontrou a certeza de que a burguesia alemã não era a classe social capaz de libertar a Alemanha. Em carta ao seu amigo e aliado político Arnold Ruge (I8O2 - I880), Marx desabafa:

A atmosfera aqui se tornou sufocante para mim. Mesmo a serviço da liberdade, é duro cumprir um trabalho servil e esgrimir-se com alfinetes em vez de coronhas. Estava cansado da hipocrisia, da tolice, da autoridade brutal, e de nossa flexibilidade, de nossas reverenciazinhas... (MARX apud LÖWY, I997, p. 77)

Marx expressa uma auto-crítica da tática neo-hegeliana de aliança com a pequena burguesia contra o absolutismo. Esses aliados não eram afiados no combate político e tinham propriedades a perder. A questão estratégica do "sujeito emancipador" ficou, em I843, sem resposta. Não sendo a burguesia prussiana, quem faria uma revolução para liquidar o antigo regime? Dentre os neo-hegelianos havia respostas distintas. Os "Livres de Berlim", no registro do idealismo utopista, pensam que o "espírito crítico" libertariam a Prússia. Arnold Ruge mergulha no pessimismo: pensa que ninguém libertaria a Prússia. Marx, junto de Ruge, em março de I843 afirma: "nosso povo não tem futuro" (MARX apud LÖWY, I997, p. I03, nota 122). Mas a desorientação foi dissipada ao longo de I843, por uma hipótese nova, influenciada pelo comunismo francês. Em I844, a hipótese será confirmada pela história. 


\section{Anais Franco-alemães: Novas Conexões Entre Liberdade e Proletariado}

"A filosofia é a cabeça dessa emancipação (do homem); o proletariado, o coração”, K. Marx (MARX apud LÖWY, I997, p. IO3, nota I22)

Os dois principais artigos de Marx nos Anais Franco-Alemães (I843) são A Questão Judaica e a Introdução à Crítica da Filosofia do Direito de Hegel ${ }^{4}$.

Em A Questão Judaica, Marx polemiza com Bruno Bauer e os "Livres de Berlim" sobre as limitações da emancipação da religião, pregada pelo ateísmo crítico. Novamente aqui, a liberdade parcelada em liberdades, pareceu a Marx, mais uma manobra enganosa do que uma estratégia de superação da servidão. Ambos, Bauer e Marx, partem do suposto de que a religião entra em conflito com a realização da liberdade. Mas Bauer afirma a necessidade de uma abolição completa da religião para se alcançar a emancipação, e Marx o critica sob dois aspectos: primeiro, que o fim da religião institucionalizada não significa o fim da religiosidade; e segundo, a abolição da religião oficial, atribuindo ao Estado caráter laico, significaria no máximo um aspecto da emancipação política, ainda distante da emancipação humana. O ano de jornalismo político na Gazeta Renana levou Marx a se afastar mais do idealismo típico dos hegelianos de esquerda. Enquanto Bauer critica o Estado cristão, Marx critica o Estado em geral, na perspectiva estratégica de uma sociedade verdadeiramente emancipada.

O dilema da religião e do Estado, para Marx se traduz nas diferenças entre emancipação política e emancipação humana. Diz: "O limite da emancipação política manifesta-se imediatamente no fato de que o Estado pode livrar-se de um limite sem que o homem dele se liberte realmente, no fato de que o Estado pode ser um Estado livre sem que o homem seja um homem livre" (MARX, I969a, p. 23-24). Aqui, a desconfiança inicial de Marx em relação ao Estado se consumou, e se converteu em negação do Estado em geral, como instituição produtora de ilusões constitucionais. Muito diferente da elaboração de I842, que sai em defesa de uma suposta "verdade racional" do direito positivo, traduzida nas leis. As determinações do terreno econômico, do regime da propriedade privada, fazem do Estado laico um instrumento de dominação tão ou mais ilusório quanto a religião, que mistifica a realidade com normatizações genéricas, 
e oculta as relações sociais reais de exploração e desigualdade. "No Estado, onde o homem é considerado um ser genérico, ele é o membro imaginário de uma soberania imaginária, está despojado de sua vida individual real e dotado de uma generalidade irreal" (MARX, I969a, p. 27), diz Marx. A "religiosidade laica" da sociedade burguesa é produzida pela distância brutal entre as leis do Estado e a vida concreta dos indivíduos. A crítica de Marx contra o Estado, tal qual pensado por Hegel, atinge o sistema idealista em seu cerne, e se torna irreversível:

No cume do Estado político, é o nascimento, por toda parte, que faz de determinados indivíduos a encarnação das mais altas tarefas públicas. As supremas atividades do Estado coincidem com os indivíduos por meio do nascimento assim como a situação de um animal, seu caráter, modo de viver, etc, lhe são imediatamente inatos. O Estado em suas funções supremas, assume uma realidade animal. A natureza se vinga de Hegel, pelo desprezo demonstrado. (MARX apud LUKÁCS, 2009b, pp. I5I-I52)

Na polêmica contra os jusnaturalistas e na defesa do direito positivo, Hegel nega a natureza como força criadora da liberdade humana. Mas essa natureza é exatamente o argumento sustentador do regime monárquico que Hegel passou a defender através de sua teoria idealista do Estado.

Em I843, Marx está ainda guiado por uma lógica democráticorevolucionária, ou jacobina, que o impulsiona a enfrentar a Monarquia, os privilégios de nascimento, a filosofia política que os legitimam. Ainda não existe o "ponto de vista do proletariado", elaborado visivelmente a partir da Introdução. Contudo, uma mudança vem junto com a crítica do Estado: a humanidade sofredora não é mais vista por Marx como pertencente à esfera dos interesses materiais privados e passa a portar o estatuto de um sofrimento "universal", que nada tem a perder na luta pela liberdade.

As insuficiências da burguesia alemã na defesa do projeto liberal fazem Marx buscar outro ator que possa dar conta da Revolução emancipatória. Assim, sua filosofia política antes norteada pela necessidade de uma "revolução democrática radical” que realizasse a transformação republicana do Estado se reorienta pela necessidade de outra revolução. Uma revolução que fosse a superação da emancipação política parcial, liderada pela burguesia da França e dos Estados Unidos, teria que incidir na esfera da sociedade econômica. A emancipação humana deveria se realizar como emancipação do proletariado. $\mathrm{O}$ caráter universal atribuído ao Estado se desloca, e encontra um conteúdo social na classe dos despossuídos. Essa percepção é estruturante de sua filosofia da história 
baseada na luta de classes. Marx afirma que

Cada esfera da sociedade civil (na Alemanha) sofre uma derrota antes de ter obtido uma vitória; ergue sua própria barreira, antes de ter derrubado a barreira que a estorva; [...] e cada classe, no preciso instante em que começa a luta contra a classe superior, permanece implicada na luta contra a classe inferior. É por isso que os príncipes estão em luta com a realeza, a burocracia com a nobreza, o burguês com todos eles, ao passo que o proletário já começa a luta contra o burguês. (MARX apud LÖWY, I997, p. IOO)

Desse quadro, Marx tira a conclusão de que aos alemães a emancipação parcial (republicana) seria utópica. Pois uma vez desencadeada uma verdadeira revolução das massas, a burguesia não teria condições de conter o proletariado (em formação, mas já independente), sem que fizesse uma aliança com a aristocracia, de forma que tudo permaneceria exatamente como estava antes. A Alemanha ou faria uma revolução emancipatória total, ou não faria revolução alguma. É em I843 que Marx enxerga o proletariado como portador do mais conseqüente papel emancipador.

Ainda assim, de acordo com Michael Löwy, Marx dos Anais FrancoAlemães não completou sua conceituação "marxista" de liberdade por causa da grande influência que Feuerbach exercia sobre seu sistema de pensamento. $O$ Marx da Introdução é tipicamente feuerbachiano. O que justifica esta afirmação são as próprias palavras de Marx: "Assim que o relâmpago do pensamento tiver penetrado no fundo desse ingênuo terreno popular, os alemães se emanciparão [...]. A filosofia é a cabeça dessa emancipação (do homem); o proletariado, o coração" (MARX apud LÖWY, I997, p. IO3, nota 122). Isso quer dizer que Marx ainda formula dentro de um registro contemplativo, que exagera a função emancipatória da filosofia crítica e atribui uma função passiva ao povo. A superação dessa dualidade entre razão e paixão, intelecto e massa, ocorre ao longo de I844, e culmina com as Teses Sobre Feuerbach em I845.

\section{A Revolta dos Tecelões da Silésia em 1844 e a Auto Emancipação dos Trabalhadores}

"Só de vocês depende, se quiserem firmemente, a saída do labirinto de misérias, dores e humilhações onde estão atolados" (TRISTAN apudLÖWY, I997, p. I33) 
Quando em junho de I844 os tecelões da Silésia se revoltaram contra seus empregadores, Marx, da França, ficou atento. No dia 4 de junho, um tecelão silesiano foi detido pela polícia no meio de um grupo que cantava uma música, considerada subversiva pelo Estado, diante da casa do fabricante Zwanziger, famoso por pagar salários miseráveis. De autoria dos tecelões, a canção demonstrou a radicalidade da categoria. Ela dizia:

"Sois a fonte da miséria

Que oprime aqui o pobre,

Sois vós que dele arranca

O pão seco da boca,

Mas vossa prata e vosso bem

Um belo dia desaparecerão

Como manteiga no sol.

O que será de vós então?"

(apud LÖWY, I997, p. I35, nota 70)

A detenção deste tecelão desencadeou uma revolta generalizada e latente na Silésia. O movimento, que apresentava caráter fortemente proletário, reivindicava melhores condições de trabalho, liberdades civis e políticas. Os tecelões paralisaram suas atividades no dia 4 de junho e marcharam armados de facas e bastões, ocuparam palácios, saquearam casas dos industriais, queimaram livros de dívidas dos patrões e destruíram cartas de crédito. No dia seguinte, 5 de junho, uma multidão de mais de 3 mil tecelões caminhou até um povoado vizinho e as cenas se repetiram. O exército foi acionado, e a multidão de trabalhadores enfrentou, corpo a corpo, o poder bélico do Estado prussiano. Nesta batalha II operários morreram e 24 ficaram feridos, tendo resultado, porém, na provisória vitória dos tecelões. No dia seguinte, 6 de junho, novos contingentes de soldados organizados em três batalhões de infantaria esmagaram a rebelião. Após esta resistência, pelo menos 38 tecelões foram detidos e condenados a trabalhos forçados. Os registros da época falam de protestos com mais de $5 \mathrm{mil}$ trabalhadores 5 (LÖWY, I997, p. I34-I37).

A canção dos tecelões é usada por Marx como prova do caráter revolucionário e comunista da revolta. Alguns de seus contemporâneos, incluindo o próprio Arnold Ruge, atribuíram à revolta uma importância mínima, associando-as

5 Os dados estão registrados em A Teoria da Revolução no Jovem Marx. Löwy os extraiu de estudos de Franz Mehring. 
às revoltas luddistas na Inglaterra, que se dirigiam contra as máquinas e não contra os capitalistas. Mas Marx, que havia elaborado no ano anterior a hipótese do "papel emancipador" do proletariado, criticado o regime da propriedade privada, e descoberto o caráter essencialmente conservador da burguesia alemã, viu nos fatos a sua teoria se materializar. Argumentou que a indústria domiciliar organizava um potencial explorador típico da grande indústria e que os motins silesianos se disseminaram por outras regiões, extravasando o conteúdo local. $\mathrm{Na}$ Boêmia, em Berlim e em Praga, greves foram desencadeadas e uma agitação geral momentânea tomou conta. Os fatos levaram Marx a adotar uma tese já presente no comunismo francês: a auto emancipação do operariado. Só que com Marx a tese foi combinada a uma filosofia dialética, e à crítica da economia política, ampliando fortemente sua consistência.

Flora Tristan (I803 - I844) foi uma socialista francesa contemporânea de Marx, muito atenta às movimentações do cartismo inglês, autora do conceito de "auto organização" e "auto emancipação" do operariado. Em I839, durante uma viagem a Inglaterra, que resultou no livro Passeios em Londres, Flora Tristan descobre o cartismo e se entusiasma com um aspecto estratégico e pouco teorizado na época: a questão da organização do movimento operário. As associações cartistas, os organismos do movimento de massas, as articulações de entidades de base são pioneiramente analisados por Flora Tristan, que inaugura na teoria aquilo que o próprio proletariado inglês já havia conquistado na prática. Daí que Flora Tristan elabora o conceito comunista de "auto emancipação", inspirado na experiência real da "auto organização" proletária. Em sua obra mais importante, União Operária (I842), Flora Tristan afirma: "Se os burgueses, na verdade, eram a 'cabeça', tinham como 'braço' o povo, do qual sabiam habilmente se servir. Quanto a vocês, proletários, vocês não têm ninguém para os ajudar. É preciso então que sejam, ao mesmo tempo, a 'cabeça' e o 'braço'” (TRISTAN apud LÖWY, I997, p. I33).

Em síntese, em I844 três fatos marcaram a formação do conceito de Marx sobre a liberdade: a revolta dos tecelões da Silésia e o contato com as associações operárias comunistas na França; os novos estudos de economia política; o primeiro encontro com seu futuro parceiro Friedrich Engels.

\section{Os Manuscritos de 1844: A Alienação Contra a Liberdade}

"Não os deuses, não a natureza, mas somente o próprio homem pode ser esta potência estranha que domina o homem" (MARX apud LUKÁCS, 2009b, p. I84) 
A elaboração do conceito de alienação nos Manuscritos é inovadora pois se associa à teoria do valor trabalho. A exteriorização do trabalho, objetivação de uma atividade subjetiva, ocorre no processo de produção de toda sociedade. Contudo, na sociedade capitalista, o produto do trabalho é imediatamente um objetomercadoria que não pertence ao sujeito-produtor. Adquire uma força estranha ao trabalhador, na qual ele não reconhece o próprio trabalho. A auto-atividade humana, ou seja, o desenvolvimento dialético imanente da personalidade de cada indivíduo, que o torna auto-consciente a partir da visão de si como objeto naquilo que produziu, a partir da identidade do subjetivo (trabalho) com o objetivo (fruto do trabalho), se converte, para classe assalariada, em auto-alienação.

A liberdade humana advém da consciência. O animal está preso à sua condição de realização imediata da vida, pela garantia física de sua sobrevivência. O humano só se realiza como humano se ultrapassar, com suas vontades, a mera sobrevivência física. O processo de alienação é um processo de desumanização, na medida em que a vida biológica do assalariado não é mais um meio de realização humana, que lhe permite sobreviver para desenvolver suas potencialidades criativas, mas um fim de sobrevivência imediata.

O proprietário, para transformar seu meio de produção em capital, necessita comprar força de trabalho (ingrediente vital do processo produtivo) e organizá-la ao longo do tempo da produção. Logo, a propriedade privada gera a necessidade da jornada de trabalho, da ordenação da mercadoria "força de trabalho" no tempo. Daí que, o tempo da reprodução do capital se converte em tempo de trabalho obrigatório para os trabalhadores. E Marx concebe o tempo livre, de fruição e vontade consciente realizada, como expressão concreta da liberdade. Uma vez que a atividade produtiva, o tempo de trabalho, o produto e o processo da produção constitui propriedade privada do capitalista, a conseqüência é a perda da liberdade como tempo livre e perda da individualidade do sujeito, que exterioriza suas capacidades humanas, objetiva seu interior-subjetivo pela apropriação de outro. O trabalho é não somente obrigatório, como constitui a "perda de si mesmo [...] a atividade como miséria, a força como impotência, a procriação como castração" (MARX, 2004, p. 83), afirma. O que era realmente externo ao homem (a propriedade privada) se converteu em "ato de exteriorização" de si. O humano realiza a liberdade em seu tempo livre, e o trabalho estranhado é a transformação da vida em tempo obrigatório de outro. Em suma, "o trabalho é a vida, e se a vida não se permutar todos os dias por alimentos sofre e, em seguida, perece. Para que a vida do homem seja uma mercadoria, é preciso, portanto, admitir a escravidão" (MARX, 2004, p. 36).

$\mathrm{Na}$ análise de Terry Eagleton, a alienação é uma espécie de moderna escravidão porque "a liberdade para Marx é uma espécie de superabundância 
criativa acima do que é materialmente essencial” (EAGLETON, I999, p. IO-II), isto é, o pleno desenvolvimento das potencialidades humanas só é possível se houver condições sociais e materiais que permitam o tempo livre. O comunismo seria então "uma sociedade em que os homens e mulheres seriam livres para florescer como fins radicais em si mesmo" (EAGLETON, I999, p. 24), sintetiza Eagleton. Isso não é possível numa sociedade em que o trabalho abstrato exerce dominação sobre o trabalho particular concreto, o valor de troca exerce dominação sobre o valor de uso. Assim que, "a supra-sunção da propriedade privada é a emancipação de todas as qualidades e sentidos humanos" (MARX, 2004, p. IOg), conclui Marx em I844.

Apesar de redefinir a liberdade a partir da economia política, nos Manuscritos Marx ainda não superou a estrutura contemplativa do pensamento de Feuerbach. A supressão da propriedade privada e da alienação não é espontânea, mas uma luta de classes. Deduzindo a supressão da propriedade privada como processo de emancipação humana, Marx afirma que "para suprimir a idéia da propriedade privada basta o comunismo pensado. Para suprimir a propriedade privada real, é necessário uma ação comunista real" (MARX apud LUKÁCS, 2009b, p. 194). Aí está o gérmen da célebre II $^{\mathrm{a}}$ Tese sobre Feuerbach ${ }^{6}$ que, de acordo com Michael Löwy, marca a última peça necessária da formação do materialismo histórico por Marx: a filosofia da práxis.

\section{Filosofia da Práxis: A Liberdade e a Revolução}

A Revolução proletária se tornou o caminho da emancipação humana para Marx a partir de I845. Após o abandono de sua postura jacobina democrática radical; após a superação do materialismo contemplativo de Feuerbach e do idealismo jovem hegeliano; após o contato com as associações operárias comunistas francesas; após os estudos científicos da economia política; após a revolta dos tecelões da Silésia, Marx reuniu as condições de formulação de uma teoria revolucionária comunista. "Sem revolução, o socialismo não poderia se realizar. Precisa-se deste ato político na medida em que se precisa de destruição e de desagregação" (MARX apud LÖWY, I997, p. I5I), diz Marx. A percepção dialética de que toda teoria é estéril quando não corresponde a uma prática socialmente determinada, e que a prática política carece da teoria para lhe dar orientação estratégica é chamada de "filosofia da práxis". Surge como fruto da formulação materialista da dialética entre o sujeito e o objeto ${ }^{7}$. A dialética entre o

6 "Os filósofos limitaram-se até agora a interpretar o mundo de diferentes maneiras. O que importa é mudá-lo" (MARX, 2008).

7 Desenvolvida por Hegel com recursos do idealismo objetivo. 
sujeito e o objeto é um movimento prático-crítico oposto ao dogmatismo. Para a filosofia da práxis, a liberdade sem conteúdo social não é nada além de uma palavra. O proletariado, definido como sujeito social da liberdade, se converte, com a filosofia da práxis, em sujeito revolucionário ativo. O proletário dá conteúdo à liberdade, pois a força de trabalho deve se reencontrar com sua finalidade: desenvolver a personalidade, as potencialidades criativas e a humanidade livre na sua máxima vontade e capacidade. Os assalariados despossuídos são os mais interessados em conquistar a liberdade humana em sua extensão mais genérica, mais desclassificada, mais verdadeira e universal. A liberdade no singular, ou seja, a liberdade histórico-concreta.

Marx, através da dialética entre o sujeito e o objeto, consegue coordenar e superar duas posições para revolução emancipadora. Por um lado, Feuerbach pensava os seres humanos como sujeitos da História, o que Marx acatou, negando, porém, o papel de sujeito revolucionário ao intelectual e transferindo-o ao proletário. Com isso supera o mito burguês do "messias emancipador", um líder civilizador esclarecido, acima das pessoas reais. Por outro lado, os materialistas franceses sobrevalorizavam os elementos materiais exteriores, como se as forças produtivas fossem autônomas. Marx acata o materialismo como princípio científico, mas insere o elemento subjetivo nas condições materiais de produção da vida, ou seja, a luta de classes como disputa de sujeitos históricos. Diz Michael Löwy:

A idéia força da auto libertação da classe operária pela revolução comunista, da auto educação do proletariado por sua própria prática revolucionária, constitui a superação dos diversos "corolários políticos" do materialismo do século XVIII, das múltiplas formas de recursos a uma entidade "acima da sociedade" (LÖWY, I997, p. I68).

Combinadas a dialética entre sujeito e objeto e a teoria da luta de classes, a violência parece um elemento irrevogável da História: "As armas da crítica não podem de fato substituir a crítica das armas; a força material tem de ser deposta por força material" (MARX, I969b, p. II7), ensina Marx em I843. Então emancipação humana, para Marx, consiste num processo violento, nas suas possibilidades e particularidades. A relação entre liberdade, ditadura do proletariado e violência revolucionária constitui outra chave conceitual. A ditadura do proletariado, ao contrário da ditadura da burguesia, só pode existir se houver liberdade mais ampla e profunda do que a liberdade jacobina: uma liberdade que só é possível mediante a condição concreta da igualdade do trabalho. 
No Manifesto Comunista de I848, o novo conceito de liberdade, inspirador de uma comunidade moderna dos meios de produção, sustenta um programa político revolucionário, que passa pela ditadura democrática do proletariado. Não se pode definir a liberdade para Marx sem associá-la à revolução comunista e à ditadura do proletariado. E a violência é uma condição da revolução. Em Marx, a definição da violência revolucionária tem origem no rigor do método materialista dialético na história, já que o controle social dos meios de produção não poderia ser espontâneo, e germinar da vontade geral do povo por sincronia. A violência revolucionária, em Marx, tem inspiração inicial jacobina, mas nega seu programa republicano e o predomínio da luta espontânea. A violência revolucionária é um elemento da luta de classes para conquista do poder político-produtivo pela classe trabalhadora. É distinta da violência revolucionária jacobina por seu rigor científico, fruto do materialismo dialético, pela sua essência sistemática e internacionalista, pela oxigenação teórica proporcionada pela filosofia da práxis, e pela sua essência comunista, ou seja, orientada pela estratégia de abolição da propriedade privada.

O programa comunista de Marx não poderia ter nascido, sem que houvesse a elaboração de um novo conceito filosófico de liberdade. E do ponto de vista marxista, qualquer liberdade concreta seria parcial, se não combinasse a socialização dos meios de produção, do poder político e cultural num novo modelo geral de sociedade. As bases que sustentam cientificamente esse programa foram lançadas ao longo da revolução teórica atravessada por Marx de I840 a I845, da sua inflexão científica e política, que o levou do universo jacobino ao internacionalismo comunista. 


\section{Referências Bibliográficas:}

EAGLETON, Terry. Marx e a Liberdade. Trad.: Marcos B. de Oliveira. São Paulo: Ed. UNESP, I999.

LÖWY, Michael, A Teoria da Revolução no Jovem Marx. Trad.: Anderson Gonçalves. Rio de Janeiro: Ed. Vozes, I997.

LUKÁCS, György, "O Jovem Hegel. Os novos problemas da pesquisa Hegeliana" (I949). In: O Jovem Marx e outros Escritos de Filosofia Política. Org. e Trad.: Carlos Nelson Coutinho e José Paulo Neto. Rio de Janeiro: Ed. UFRJ, 2009a. Cap. III, p. 89-II9. "O Jovem Marx. Sua evolução filosófica de I840 a I844" (I955). In: O Jovem Marx e outros Escritos de Filosofia Política. Org. e Trad.: Carlos Nelson Coutinho e José Paulo Neto. Rio de Janeiro: Ed. UFRJ, 2009b. Cap. IV, p. I2I-2O2.

MARX, Karl. Teses sobre Feuerbach. São Paulo: Ed. Conrad, 2008. Manuscritos Econômico-Filosóficos. Trad.: Jesus Ranieri. São Paulo: Ed. Boitempo, 2004 . . A Questão Judaica. Rio de Janeiro: Ed. Laemmert, I969a. " "Introdução à Crítica da Filosofia do Direito de Hegel", In: $A$ Questão Judaica. Rio de Janeiro: Ed. Laemmert, I969b. Apêndice, p. IO3-I28. . "Sobre a Censura e a Liberdade de Opinião". Trad.: Claudia

Schilling. In: Revista Oitenta, Vol I. Brasil: Ed. L\&PM, I979. p. 43-72.

\footnotetext{
Wor

Joana Salém Vasconcelos é graduanda em História pela USP.

E-mail: joana_salem@yahoo.com.br
} 